\title{
ANALISIS EX-ANTE KEBERLANJUTAN PROGRAM MINAPOLITAN
}

\author{
Siti Hajar Suryawati dan Agus Heri Purnomo \\ Balai Besar Riset Sosial Ekonomi Kelautan dan Perikanan \\ JI. KS. Tubun Petamburan VI Jakarta 10260 \\ Telp. (021) 53650162, Fax. (021)53650159 \\ Diterima 21 Februari 2011 - Disetujui 21 Mei 2011
}

\begin{abstract}
ABSTRAK
Penelitian ini dilakukan pada bulan Agustus - Desember 2010, bertujuan untuk: (i) menentukan indeks keberlanjutan program minapolitan di lokasi sebagaimana tertuang dalam Keputusan Menteri No. KEP 32/MEN/2010, (ii) mengidentifikasi atribut pengungkit, dan (iii) menyusun arahan kebijakan. Indeks keberlanjutan diukur untuk enam (6) dimensi keberlanjutan minapolitan, yang jenisnya ditetapkan berdasarkan pendalaman literatur: ekologi, ekonomi, politik, sosial-budaya, hukumkelembagaan, dan teknologi-infrastruktur. Data primer dari hasil mail survey ke 197 kabupaten/ kota dianalisis dengan teknik ordinasi Multidimensional Scalling (MDS) menggunakan perangkat RAP-Minapolitan, yang dimodifikasi dari perangkat RAPFISH (Rapid Appraisal for Fisheries). Analisis ini digunakan untuk menduga prospek keberlanjutan berdasarkan pengukuran variabel-variabel kini. Hasil analisis menunjukkan bahwa indeks keberlanjutan program minapolitan untuk keenam dimensi adalah sebagai berikut : ekologi kurang berkelanjutan; ekonomi kurang berkelanjutan; politik sangat berkelanjutan; sosial-budaya cukup berkelanjutan; hukum-kelembagaan sangat berkelanjutan; teknologi-infrastruktur kurang berkelanjutan. Hasil kajian menunjukkan bahwa atribut pengungkit untuk masing-masing dimensi memerlukan prioritas kebijakan untuk meningkatkan peluang keberlanjutan program minapolitan. Atribut-atribut tersebut adalah: Jarak lokasi usaha perikanan dengan pemukiman, kejadian kekeringan, produktivitas usaha (dimensi ekologi); Ketersediaan SDM perikanan (dimensi ekonomi); Sinkronisasi kebijakan pusat - daerah, trend politik lokal dan dominasi kelompok politik tertentu (dimensi politik); Akses masyarakat terhadap perikanan dan peran masyarakat adat (dimensi sosial-budaya); Ketersediaan industri pengolahan limbah (dimensi teknologi-infrastruktur).
\end{abstract}

Kata kunci: keberlanjutan, minapolitan, perikanan, multidimensional scaling

\section{Abstract : Ex-ante Analysis of the Minapolitan Program Sustainability. by : Siti Hajar Suryawati and Agus Heri Purnomo}

This research was conducted in August - December 2010, and aimed to (i) determine the sustainability index of minapolitan programs in locations referred to in the Ministerial Decree No. KEP 32/MEN/2010, (ii) identifying leverage factors (attributes), and (iii) formulate the relevant policy direction. The sustainability indexes were measured for six (6) minapolitan sustainability dimensions, based on literature reviews of ecology, economy, politics, social and culture, legal and institution, and technology and infrastructure dimensions. Primary data collected from the mail survey to 197 districts/municipalities listed in the decree were analysed following the multidimensional scalling (MDS) approach using the RAP-Minapolitan software, which was a modification of the RAPFISH (Rapid Appraisal for Fisheries) software. This analysis method can be used to assess sustainability prospects based on the measurement of current conditions of relevant variables. Results of this research show that the sustainability indice of the minapolitan program for the six dimension are: ecology less sustainable; economy less sustainable; politics very sustainable; social and culture fairly sustainable; legal and institution very sustainable; and technology and infrastructure (less sustainable). Results of this research show that leverage factors (attributes) of each dimension need prioritized policy to impove sustainability prospect of 
the minapolitan program. These are: distance between fisheries business center and residence complexes, business productivity (ecologic dimension); fishery human resources (economy dimension); state - region policy synchronization, trend of local politics and domination of particular political groups (political dimension); people access to fishery and customary community role (social-culture dimension); availability of waste treatment facility (technology and infrastructure dimension).

\section{Keywords: sustainability, minapolitan, fishery, multidimensional scaling}

\section{PENDAHULUAN}

Konsep pembangunan berkelanjutan diperkenalkan oleh The World Commission on Environment and Development (WCED) pada tahun 1987. Dalam laporan WCED tersebut, pemahaman tentang pembangunan berkelanjutan dideskripsikan sebagai pembangunan yang dapat memenuhi kebutuhan saat ini tanpa membatasi peluang generasi mendatang untuk memenuhi kebutuhannya. Mengacu pada pemahaman tersebut, Beller (1990) memberikanan penekanan pada pentingnya prinsip Justice of Fairness, yang menuntut tanggung jawab semua generasi terkait hal ini. Konsep pembangunan berkelanjutan, yang juga berlaku untuk pembangunan sektor perikanan, bersifat multi aspek. Aspek-aspek tersebut adalah aspek ekologi, ekonomi, sosial-budaya, hukum dan kelembagaan, teknologi dan infrastruktur, dan politik.

Sementara itu, Kay dan Alder (1999) menyebutkan adanya 3 (tiga) tema yang terkandung dalam definisi pembangunan berkelanjutan, yaitu: (1) integritas lingkungan, (2) efisiensi ekonomi, dan (3) keadilan kesejahteraan (equity). Pernyataan senada dikemukakan oleh Munasinghe (1993), yang menyebutkan bahwa pembangunan dikatakan berkelanjutan jika memenuhi persyaratan yang terkait 3 (tiga) dimensi, yaitu: (1) secara ekonomi dapat efisien serta layak, (2) secara sosial berkeadilan, dan (3) secara ekologis lestari (ramah lingkungan).

Kesamaan pandang masyarakat internasional tentang konsep keberlanjutan membawa implikasi berupa perlunya penerapan konsep tersebut dalam setiap kebijakan maupun program pembangunan pemerintah di semua negara. Kementrian Kelautan dan Perikanan (KKP) mengimplementasikannya melalui program minapolitan. Program Minapolitan adalah program pembangunan perikanan yang difokuskan pada perbaikan sistem fungsional desa-desa berdasarkan hirarki keruangannya.

Dalam rangka mengetahui dan meningkatkan prospek keberlanjutan program minapolitan perlu dilakukan analisis pendugaan keberlanjutan program minapolitan di kabupaten-kabupaten / kota yang termasuk dalam daftar dalam Keputusan Menteri (Kepmen) KP No 32/MEN/ 2010 tersebut menurut aspek-aspek yang relevan, berdasarkan pada kondisi kini dari berbagai dimensi terkait.

Berdasarkan hasil telaah terhadap berbagai publikasi (Etkin, 1992 dalam Gallopin, 2003; Dalay-Clayton dan Bass, 2002; Dahuri, 2004), dapat dirangkum sejumlah dimensi yang perlu dipertimbangkan dalam analisis keberlanjutan, yaitu ekologi, ekonomi, politik, sosial budaya, hukum dan kelembagaan, dan teknologi dan infrastruktur. Mengingat pentingnya konsep pembangunan berkelanjutan di semua bidang sebagaimana diperkenalkan oleh WCED dan pemahaman yang berkembang di literatur mengenai konsep tersebut, dilakukan penelitian status keberlanjutan pelaksanaan program Minapolitan berdasarkan berbagai dimensi tersebut. Tujuan penelitian ini adalah untuk menprediksi keberlanjutan Minapolitan, mengidentifikasi faktorfaktor atau atribut-atribut yang sensitif berpengaruh terhadap keberlanjutan 
minapolitan dan menyusun arahan kebijakan pengembangan kawasan minapolitan di lokasi yang sudah ditentukan dalam Keputusan Menteri Kelautan dan Perikanan (Kepmen KP) No. KEP 32/MEN/2010.

\section{METODOLOGI}

\section{Cakupan dan Pendekatan Penelitian}

Penelitian keberlanjutan program minapolitan dianalisis secara makro pada tingkat nasional. Penelitian ini dilaksanakan berdasarkan aspek-aspek keberlanjutan yang ditetapkan melalui pendalaman literatur (Etkin, 1992 dalam Gallopin, 2003; DalayClayton dan Bass, 2002; Dahuri, 2004).

\section{Tempat dan Waktu}

Lokasi penelitian meliputi seluruh kabupaten dan kota yang tercakup dalam Kepmen KP No. KEP 32/MEN/2010 sedangkan pelaksanaan pengumpulan data melalui survei dilakukan pada Bulan OktoberDesember 2010.

\section{Jenis dan Sumber Data}

Jenis data yang diperlukan dalam pemetaan status keberlanjutan pemetaan Minapolitan adalah data primer berupa atribut-atribut yang terkait dengan 6 (enam) dimensi keberlanjutan yaitu: dimensi ekologi, ekonomi, politik, sosialbudaya, hukum dan kelembagaan, serta teknologi dan infrastruktur (Tabel 1). Atribut-atribut tersebut dipilih dan diuji berdasarkan prosedur dan kriteria sebagaimana dijelaskan dalam Kavanagh (2001).

\section{Metode Analisis}

Metode analisis yang digunakan dalam penelitian ini adalah metode analisis statistik multivariat berupa analisis multidimensional scalling (MDS). Teknik ini yang merupakan sebuah pendekatan statistik multivariat berbasis objek (minapolitan) yang memungkinkan transformasi multidimensi menjadi dimensi yang lebih sederhana (Fauzi dan Anna, 2005).

Tabel 1. Dimensi, Atribut dan Skor yang Terpilih Untuk Melakukan Pengkajian Keberlanjutan Program Minapolitan ii Lokasi-Lokasi Sesuai KEPMEN KP32/2010.

Table 1. Dimensions, Attributes and Scores Selected for Sustainability Assessment of Minapolitan Programing Locations Stated in the Ministrial Decree No. 32/2010

\begin{tabular}{|c|c|c|c|}
\hline $\begin{array}{l}\text { No/ } \\
\text { No }\end{array}$ & $\begin{array}{l}\text { Atribut / } \\
\text { Attributes }\end{array}$ & & $\begin{array}{l}\text { Skor/ } \\
\text { Scores }\end{array}$ \\
\hline \multicolumn{4}{|c|}{ Dimensi Ekologi (Ecological Dimensions) } \\
\hline \multirow[t]{3}{*}{1} & \multirow{3}{*}{$\begin{array}{l}\text { Tingkat pemanfaatan } \\
\text { sumberdaya perikanan/Fisheries } \\
\text { resource exploitation rate }\end{array}$} & $0=$ & $\begin{array}{l}\text { Jauh melebihi atau dibawah kapasitas / } \\
\text { Farover orundercapacity }\end{array}$ \\
\hline & & $1=$ & $\begin{array}{l}\text { Agak melebihi atau agak dibawah kapasitas/ } \\
\text { Slightly exceedor slightly be low capacity }\end{array}$ \\
\hline & & $2=$ & Optimal /Optimal \\
\hline 2 & $\begin{array}{l}\text { Kesuburan sumberdaya } \\
\text { perikanan/Fisheries resource } \\
\text { fertility }\end{array}$ & $\begin{array}{l}0= \\
1= \\
2=\end{array}$ & $\begin{array}{l}\text { Tidak subur /Infertile } \\
\text { Kesuburan sedang / Fertility is average } \\
\text { Sangat subur / High fertility }\end{array}$ \\
\hline 3 & $\begin{array}{l}\text { Produktivitas usaha perikanan/ } \\
\text { Fisheries business productivity }\end{array}$ & $\begin{array}{l}0= \\
1= \\
2=\end{array}$ & $\begin{array}{l}\text { Rendah / Low } \\
\text { Sedang / Average } \\
\text { Tinggi / High }\end{array}$ \\
\hline \multirow[t]{3}{*}{4} & \multirow{3}{*}{$\begin{array}{l}\text { Penggunaan hasil samping } \\
\text { (misalnya: penggunaan ikan } \\
\text { rucah sebagai pakan, dan lain- } \\
\text { lain) / By catch utilization }\end{array}$} & $\begin{array}{l}0= \\
1=\end{array}$ & $\begin{array}{l}\text { Tidak dimanfaatkan /Not used } \\
\text { Sebagian kecil dimanfaatkan /Utilizaton in a } \\
\text { small portion }\end{array}$ \\
\hline & & $2=$ & $\begin{array}{l}\text { Sebagian besar dimanfaatkan /Utilization in a big } \\
\text { portion }\end{array}$ \\
\hline & & $3=$ & Seluruhnya dimanfaatkan /Full exploited \\
\hline
\end{tabular}




\section{Lanjutan Tabel 1/Continues Table 1}

\begin{tabular}{|c|c|c|c|}
\hline $\begin{array}{l}\text { No/ } \\
\text { No }\end{array}$ & $\begin{array}{l}\text { Atribut / } \\
\text { Attributes }\end{array}$ & & $\begin{array}{l}\text { Skor/ } \\
\text { Scores }\end{array}$ \\
\hline 5 & Curah hujan /Precipitation & $\begin{array}{l}0= \\
1= \\
2=\end{array}$ & $\begin{array}{l}\text { Tinggi / High } \\
\text { Sedang / Medium } \\
\text { Rendah / Low }\end{array}$ \\
\hline 6 & $\begin{array}{l}\text { Ekstrimitas iklim / } \\
\text { Climate extrimity }\end{array}$ & $\begin{array}{l}0= \\
1=\end{array}$ & $\begin{array}{l}\text { Iklim ekstrim/Extreme climate } \\
\text { Iklim sedang /Medium climate }\end{array}$ \\
\hline 7 & $\begin{array}{l}\text { Kejadian kekeringan/ } \\
\text { Drought event }\end{array}$ & $\begin{array}{l}0= \\
1= \\
2=\end{array}$ & $\begin{array}{l}\text { Sering /Often } \\
\text { Kadang-kadang /Sometimes } \\
\text { Tidak pernah terjadi /Never }\end{array}$ \\
\hline 8 & Kejadian banjir /Flood event & $\begin{array}{l}0= \\
1= \\
2=\end{array}$ & $\begin{array}{l}\text { Sering /Often } \\
\text { Kadang-kadang /Sometimes } \\
\text { Tidak pernah terjadi /Never }\end{array}$ \\
\hline 9 & $\begin{array}{l}\text { Jarak lokasi usaha perikanan } \\
\text { dengan pemukiman penduduk/ } \\
\text { Distance of business centers to } \\
\text { residence }\end{array}$ & $\begin{array}{l}0= \\
1= \\
2= \\
3= \\
4=\end{array}$ & $\begin{array}{l}\text { Di lokasi pemukiman /In residential location } \\
\text { Dekat /Close } \\
\text { Agak dekat /Somehow close } \\
\text { Agak jauh /Somehow far } \\
\text { Jauh /Far }\end{array}$ \\
\hline 10 & $\begin{array}{l}\text { Pengetahuan tentang } \\
\text { lingkungan/Knowledge on } \\
\text { environment }\end{array}$ & $\begin{array}{l}0= \\
1= \\
2=\end{array}$ & $\begin{array}{l}\text { Sangat minim /Very minimal } \\
\text { Cukup /Enough } \\
\text { Luas /Maximal }\end{array}$ \\
\hline
\end{tabular}

\section{Dimensi Ekonomi (Economical Dimensions)}

$1 \quad$ Ketersediaan pasar ikan/ The availability of fish market

2

$$
\text { Keragaman komoditas }
$$
unggulan /Variability in primary commodity

$$
\text { Pemilikan asset produksi oleh }
$$
masyarakat / People production asset

Kontribusi terhadap Produk Domestik Regional Bruto (PDRB) /Contribution to GRDP Kontribusi terhadap Pendapatan Asli Daerah (PAD) untuk bidang perikanan /Contribution to regional fisheries revenue (PAD) for fisheries sector Perubahan nilai APBD perikanan

\section{$0=$} $1=$

$2=$ $0=$ selama 5 tahun terakhir / Change in regional budget in the last 5 years
Tidak ada /Not available

Ada tetapi tidak mampu memberikan pelayanan maksimal /Available but not able to provide maximum services

Tersedia dan mampu memberikan pelayanan maksimal, mengikuti setiap dinamika ekonomi / Available and capable of providingoptimal service, following everyeconomicdynamics

Sangat terbatas / Limited

Ada variasi / There are variations

Sangat beragam /Very diverse

Sangat tinggi / Very high

Tinggi / High

Sedang /Medium

$$
\text { Rendah /Low }
$$

Rendah (<10\%) /Low

Sedang (10 - $20 \%) /$ Medium

Tinggi (> 20\%) / High

Rendah (<30\%) /Low

Sedang (30-50\%) /Medium

Tinggi (> 50\%) / High

Cenderung berkurang / Tend to decrease

Cenderung tetap /Tend to remain

Cenderung bertambah / Tend to increase 


\section{Lanjutan Tabel 1/Continues Table 1}

\begin{tabular}{|c|c|c|c|}
\hline $\begin{array}{l}\text { No/ } \\
\text { No }\end{array}$ & $\begin{array}{l}\text { Atribut / } \\
\text { Attributes }\end{array}$ & & $\begin{array}{l}\text { Skor/ } \\
\text { Scores }\end{array}$ \\
\hline 7 & $\begin{array}{l}\text { Harga komoditas perikanan/ } \\
\text { Fish product prices }\end{array}$ & $\begin{array}{l}0= \\
1= \\
2= \\
3=\end{array}$ & $\begin{array}{l}\text { Sangat tinggi/Very high } \\
\text { Tinggi /High } \\
\text { Sedang /Medium } \\
\text { Rendah/Low }\end{array}$ \\
\hline 8 & $\begin{array}{l}\text { Potensi pengembangan usaha } \\
\text { agroindustri /Potential of } \\
\text { agroindustry development }\end{array}$ & $\begin{array}{l}0= \\
1= \\
2=\end{array}$ & $\begin{array}{l}\text { Tidak potensial /Not potential } \\
\text { Cukup berpotensi /Enough potential } \\
\text { Sangat besarpotensinya/Very potential }\end{array}$ \\
\hline 9 & $\begin{array}{l}\text { Ketersediaan SDM perikanan/ } \\
\text { Availability of fishery human } \\
\text { resources }\end{array}$ & $\begin{array}{l}0= \\
1= \\
2= \\
3=\end{array}$ & $\begin{array}{l}\text { Sedikit / Low } \\
\text { Sedang /Medium } \\
\text { Tinggi /High } \\
\text { Sangat tinggi / Very high }\end{array}$ \\
\hline 10 & $\begin{array}{l}\text { Penyerapan tenaga kerja } \\
\text { perikanan / Labor force use by } \\
\text { fisheries sector }\end{array}$ & $\begin{array}{l}0= \\
1= \\
2=\end{array}$ & $\begin{array}{l}\text { Rendah / Low } \\
\text { Sedang /Medium } \\
\text { Tinggi / High }\end{array}$ \\
\hline 11 & $\begin{array}{l}\text { Tingkat ketergantungan } \\
\text { konsumen/Level of consumer } \\
\text { dependability }\end{array}$ & $\begin{array}{l}0= \\
1= \\
2=\end{array}$ & $\begin{array}{l}\text { Rendah /Low } \\
\text { Sedang /Medium } \\
\text { Tinggi/High }\end{array}$ \\
\hline 12 & $\begin{array}{l}\text { Kelayakan usaha perikanan/ } \\
\text { Fisheries business feasibility }\end{array}$ & $\begin{array}{l}0= \\
1= \\
2=\end{array}$ & $\begin{array}{l}\text { Tidak layak /Not feasible } \\
\text { Impas/Break even point } \\
\text { Layak /Feasible }\end{array}$ \\
\hline 13 & $\begin{array}{l}\text { Keuntungan dalam usaha } \\
\text { perikanan / Profit in fisheries } \\
\text { business }\end{array}$ & $\begin{array}{l}0= \\
1= \\
2= \\
3= \\
4=\end{array}$ & $\begin{array}{l}\text { Rugi besar /Largeloss } \\
\text { Rugi sedikit /Losslittle } \\
\text { Kembali modal /Break even } \\
\text { Keuntungan marginal /Marginalprofit } \\
\text { Sangat menguntungkan /Highlyprofitable }\end{array}$ \\
\hline 14 & $\begin{array}{l}\text { Besarnya subsidi / Level of } \\
\text { subsidy }\end{array}$ & $\begin{array}{l}0= \\
1= \\
2= \\
3= \\
4=\end{array}$ & $\begin{array}{l}\text { Keharusan mutlak /Absolute necessity } \\
\text { Sangat tergantung /Highly dependent } \\
\text { Besar / Large } \\
\text { Sedikit / Little } \\
\text { Tidak ada /None }\end{array}$ \\
\hline 15 & $\begin{array}{l}\text { Transfer keuntungan /Benefit } \\
\text { transfer }\end{array}$ & $\begin{array}{l}0= \\
1= \\
2=\end{array}$ & $\begin{array}{l}\text { Lebih banyak di peduduk luar daerah /Outsiders } \\
\text { enjoy bogger benefits } \\
\text { Seimbang antara lokal dan luar daerah /Outsiders } \\
\text { and local populations enjoy benefits equally } \\
\text { Terutama berada di penduduk lokal / Local people } \\
\text { enjoy more benefits }\end{array}$ \\
\hline 16 & $\begin{array}{l}\text { Alternatif usaha di luar bidang } \\
\text { perikanan /Job alternative } \\
\text { outside fisheries }\end{array}$ & $\begin{array}{l}0= \\
1= \\
2=\end{array}$ & $\begin{array}{l}\text { Banyak /Many alternatives } \\
\text { Sedikit alternatif /Fewalternatives } \\
\text { Tidak ada alternatif /Noalternative }\end{array}$ \\
\hline
\end{tabular}

\section{Dimensi Politik (Political Dimensions)}

1 Trend politik lokal (kabupaten) / $0=$ (Local (district) political trend)
Cenderung hanya mementingkan tujuan-tujuan politis/Tend to focus on political purposes

$1=\quad$ Berorientasi pada pembangunan dan pensejahteraan masyarakat /Development and welfare-oriented 


\section{Lanjutan Tabel 1/Continues Table 1}

\begin{tabular}{|c|c|c|c|}
\hline $\begin{array}{l}\text { No/ } \\
\text { No }\end{array}$ & $\begin{array}{l}\text { Atribut / } \\
\text { Attributes }\end{array}$ & & $\begin{array}{l}\text { Skor/ } \\
\text { Scores }\end{array}$ \\
\hline \multirow[t]{2}{*}{2} & $\begin{array}{l}\text { Trend politik regional (propinsi)/ } \\
\text { Regional (provincial) political }\end{array}$ & $0=$ & $\begin{array}{l}\text { Cenderung hanya mementingkan tujuan-tujuan } \\
\text { politis / Trend to focus on political purposes) }\end{array}$ \\
\hline & & $1=$ & $\begin{array}{l}\text { Berorientasi pada pembangunan dan } \\
\text { pensejahteraan masyarakat / Development and } \\
\text { welfare-oriented }\end{array}$ \\
\hline \multirow[t]{2}{*}{3} & $\begin{array}{l}\text { Trend politik nasional (pusat)/ } \\
\text { National political trend }\end{array}$ & $0=$ & $\begin{array}{l}\text { Cenderung hanya mementingkan tujuan-tujuan } \\
\text { politis / Trend to focus on political purposes }\end{array}$ \\
\hline & & $1=$ & $\begin{array}{l}\text { Berorientasi pada pembangunan dan } \\
\text { pensejahteraan masyarakat /Development and } \\
\text { welfare-oriented }\end{array}$ \\
\hline 4 & $\begin{array}{l}\text { Dominasi kelompok politik } \\
\text { tertentu /Domination of } \\
\text { particular political group }\end{array}$ & $\begin{array}{l}0= \\
1=\end{array}$ & $\begin{array}{l}\text { Ada /Available } \\
\text { Tidak ada /None }\end{array}$ \\
\hline 5 & $\begin{array}{l}\text { Keterpaduan kebijakan pusat } \\
\text { dan daerah / Harmony between } \\
\text { local and national policy }\end{array}$ & $\begin{array}{l}0= \\
1= \\
2=\end{array}$ & $\begin{array}{l}\text { Tidak sinkron / No syncronizes } \\
\text { Kurang sinkron / Less syncronized } \\
\text { Sinkron /Syncronized }\end{array}$ \\
\hline \multicolumn{4}{|c|}{ Dimensi Sosial Budaya (Socio-Cultural Dimensions) } \\
\hline 1 & $\begin{array}{l}\text { Tingkat pendidikan formal } \\
\text { masyarakat /People formal } \\
\text { educational acchivement }\end{array}$ & $\begin{array}{l}0= \\
1= \\
2=\end{array}$ & $\begin{array}{l}\text { Rendah / Low } \\
\text { Sedang /Medium } \\
\text { Tinggi / High }\end{array}$ \\
\hline 2 & $\begin{array}{l}\text { Keterlibatan nyata dalam bidang } \\
\text { perikanan/Actual participation } \\
\text { in fisheries sector }\end{array}$ & $\begin{array}{l}0= \\
1= \\
2=\end{array}$ & $\begin{array}{l}\text { Tidak ada /No } \\
\text { Sedikit / Less } \\
\text { Banyak / Many }\end{array}$ \\
\hline 3 & $\begin{array}{l}\text { Pemberdayaan masyarakat } \\
\text { perikanan /Fisheries people } \\
\text { empowerement }\end{array}$ & $\begin{array}{l}0= \\
1= \\
2=\end{array}$ & $\begin{array}{l}\text { Tidak ada /No } \\
\text { Sedikit / Less } \\
\text { Banyak / Many }\end{array}$ \\
\hline 4 & $\begin{array}{l}\text { Peran masyarakat adat dalam } \\
\text { kegiatan perikanan / Role of } \\
\text { customary arrangement in } \\
\text { fisheries }\end{array}$ & $\begin{array}{l}0= \\
1= \\
2=\end{array}$ & $\begin{array}{l}\text { Tidak ada /None } \\
\text { Sedikit / Little } \\
\text { Banyak /Many }\end{array}$ \\
\hline 5 & $\begin{array}{l}\text { Peran masyarakat dalam } \\
\text { pengelolaan sumberdaya } \\
\text { perikanan / } \\
\text { Peole interraletionship in } \\
\text { fisheries management }\end{array}$ & $\begin{array}{l}0= \\
1= \\
2=\end{array}$ & $\begin{array}{l}\text { Tidak aktif /Passive } \\
\text { Biasa /Moderate } \\
\text { Aktif /active }\end{array}$ \\
\hline 6 & $\begin{array}{l}\text { Akses masyarakat terhadap } \\
\text { perikanan /People access to } \\
\text { fisheries }\end{array}$ & $\begin{array}{l}0= \\
1=\end{array}$ & $\begin{array}{l}\text { Akses sulit (Difficult access) } \\
\text { Akses mudah (Easy access) }\end{array}$ \\
\hline 7 & $\begin{array}{l}\text { Frekuensi konflik /Frequency of } \\
\text { conflict }\end{array}$ & $\begin{array}{l}0= \\
1= \\
2=\end{array}$ & $\begin{array}{l}\text { Banyak (Many) } \\
\text { Sedikit (Lottle) } \\
\text { Tidak ada (None) }\end{array}$ \\
\hline 8 & $\begin{array}{l}\text { Alokasi waktu untuk usaha } \\
\text { perikanan / Time allocation on } \\
\text { fisheries business }\end{array}$ & $\begin{array}{l}0= \\
1= \\
2= \\
3=\end{array}$ & $\begin{array}{l}\text { Hanya hobby (Just hobby) } \\
\text { Paruh waktu (Part time) } \\
\text { Musiman (Seasonal) } \\
\text { Penuh waktu (Full time) }\end{array}$ \\
\hline
\end{tabular}




\section{Lanjutan Tabel 1/Continues Table 1}

\begin{tabular}{|c|c|c|c|}
\hline $\begin{array}{l}\text { No/ } \\
\text { No }\end{array}$ & $\begin{array}{l}\text { Atribut / } \\
\text { Attributes }\end{array}$ & & $\begin{array}{l}\text { Skor/ } \\
\text { Scores }\end{array}$ \\
\hline \multirow[t]{3}{*}{9} & \multirow{3}{*}{$\begin{array}{l}\text { Jumlah desa dengan penduduk } \\
\text { bekerja di sektor perikanan / } \\
\text { Villages with predominantly } \\
\text { fishery people }\end{array}$} & $0=$ & Tidak adadi desa manapun /No village \\
\hline & & $1=$ & Desa tertentu saja /Some village \\
\hline & & $2=$ & Semua desa /All village \\
\hline \multirow[t]{3}{*}{10} & \multirow{3}{*}{$\begin{array}{l}\text { Kerjasama dalam usaha di } \\
\text { bidang perikanan /Cooperation } \\
\text { in fishery-based businesses }\end{array}$} & $0=$ & $\begin{array}{l}\text { Pekerjaan dilakukan secara individu / } \\
\text { Work is carried outindividually }\end{array}$ \\
\hline & & $1=$ & $\begin{array}{l}\text { Pekerjaan dilakukan bersama keluarga saja/ } \\
\text { Workcarried outwiththe familyalone }\end{array}$ \\
\hline & & $2=$ & $\begin{array}{l}\text { Pekerjaan dilakukan secara kelompok / } \\
\text { Work is performedin groups }\end{array}$ \\
\hline \multirow[t]{4}{*}{11} & \multirow{4}{*}{$\begin{array}{l}\text { Partisipasi keluarga dalam usaha } \\
\text { perikanan /Family involvement } \\
\text { in fishery-based business }\end{array}$} & $0=$ & Tidak ada /No \\
\hline & & $1=$ & $\begin{array}{l}\text { Sedikit dari anggota keluarga/ } \\
\text { A bit of family members }\end{array}$ \\
\hline & & $2=$ & $\begin{array}{l}\text { Sebagian besar dari anggota keluarga / } \\
\text { Most of the members of the family }\end{array}$ \\
\hline & & $3=$ & $\begin{array}{l}\text { Semua anggota keluarga / } \\
\text { All members of the family }\end{array}$ \\
\hline \multicolumn{4}{|c|}{ Dimensi Hukum dan Kelembagaan (Legal and Institutional Dimensions) } \\
\hline \multirow[t]{3}{*}{1} & \multirow{3}{*}{$\begin{array}{l}\text { Kerjasama pemerintah pusat } \\
\text { dan daerah /Cooperation } \\
\text { between local \& national } \\
\text { government }\end{array}$} & $0=$ & Tidak ada /Not available \\
\hline & & $1=$ & $\begin{array}{l}\text { Ada tetapi tidak berjalan / } \\
\text { Available but not running }\end{array}$ \\
\hline & & $2=$ & Ada dan berjalan /Available and running well \\
\hline \multirow[t]{3}{*}{2} & \multirow{3}{*}{$\begin{array}{l}\text { Keberadaan perangkat hukum } \\
\text { adat/agama/Availability of local } \\
\text { legal/religion }\end{array}$} & $0=$ & Tidak ada /Not available \\
\hline & & $1=$ & Ada tetapi tidak berjalan /Available but not running \\
\hline & & $2=$ & Ada dan berjalan /Available and running well \\
\hline \multirow[t]{3}{*}{3} & \multirow{3}{*}{$\begin{array}{l}\text { Keberadaan peraturan } \\
\text { perundangan pengembangan } \\
\text { minapolitan / Availability of } \\
\text { regulation for minapolitan } \\
\text { development }\end{array}$} & $0=$ & Tidak ada /Not available \\
\hline & & $1=$ & Ada tetapi tidak berjalan /Available but not running \\
\hline & & $2=$ & Ada dan berjalan /Available and running \\
\hline \multirow[t]{3}{*}{4} & \multirow{3}{*}{$\begin{array}{l}\text { Mekanisme kerjasama lintas } \\
\text { sektoral dalam program } \\
\text { perikanan/minapolitan /Inter } \\
\text { sector cooperation mechanism } \\
\text { in minapolitan program }\end{array}$} & $0=$ & Tidak ada /Not available \\
\hline & & $1=$ & Ada tetapi tidak berjalan /Available but not running \\
\hline & & $2=$ & Ada dan berjalan/Available and running well \\
\hline \multirow[t]{3}{*}{5} & \multirow{3}{*}{$\begin{array}{l}\text { Keberadaan lembaga kelompok } \\
\text { pendukung kelompok nelayan } \\
\text { atau pembudidaya /Availability } \\
\text { of supporting institution for } \\
\text { fishers group }\end{array}$} & $0=$ & Tidak ada /Not available \\
\hline & & $1=$ & Ada tetapi tidak berjalan /Available but not running \\
\hline & & $2=$ & Ada dan berjalan (Available and running well) \\
\hline \multirow[t]{3}{*}{6} & \multirow{3}{*}{$\begin{array}{l}\text { Keberadaan lembaga keuangan } \\
\text { mikro /Availability of micro } \\
\text { financing mechanism }\end{array}$} & $0=$ & Tidak ada (Not available) \\
\hline & & $1=$ & $\begin{array}{l}\text { Ada tetapi tidak berjalan (Available but not } \\
\text { running) }\end{array}$ \\
\hline & & $2=$ & Ada dan berjalan (Available and running well) \\
\hline
\end{tabular}




\section{Lanjutan Tabel 1/Continues Table 1}

\begin{tabular}{|c|c|c|c|}
\hline $\begin{array}{l}\text { No/ } \\
\text { No }\end{array}$ & $\begin{array}{l}\text { Atribut / } \\
\text { Attributes }\end{array}$ & & $\begin{array}{l}\text { Skor/ } \\
\text { Scores }\end{array}$ \\
\hline \multirow[t]{3}{*}{7} & \multirow{3}{*}{$\begin{array}{l}\text { Keberadaan lembaga sosial/ } \\
\text { Availability ofsocial institution }\end{array}$} & $0=$ & Tidak ada (Not available) \\
\hline & & $1=$ & $\begin{array}{l}\text { Ada tetapi tidak berjalan (Available but not } \\
\text { running) }\end{array}$ \\
\hline & & $2=$ & Ada dan berjalan (Available and running well) \\
\hline \multirow[t]{3}{*}{8} & \multirow{3}{*}{$\begin{array}{l}\text { Keberadaan lembaga } \\
\text { penyuluhan perikanan/ } \\
\text { Availability of fisheries extension } \\
\text { service institution }\end{array}$} & $0=$ & Tidak ada (Not available) \\
\hline & & $1=$ & $\begin{array}{l}\text { Ada tetapi tidak berjalan (Available but not } \\
\text { running) }\end{array}$ \\
\hline & & $2=$ & Ada dan berjalan (Available and running well) \\
\hline \multirow[t]{3}{*}{9} & \multirow{3}{*}{$\begin{array}{l}\text { Keberadaan kelompok } \\
\text { pengawas / Existence of } \\
\text { surveillance body }\end{array}$} & $0=$ & Tidak ada (Not available) \\
\hline & & $1=$ & $\begin{array}{l}\text { Ada tetapi tidak berjalan (Available but not } \\
\text { running) }\end{array}$ \\
\hline & & $2=$ & Ada dan berjalan (Available and running well) \\
\hline \multirow[t]{3}{*}{10} & \multirow{3}{*}{$\begin{array}{l}\text { Keberadaan kelompok nelayan } \\
\text { dan pembudidaya /Availability } \\
\text { of fishers group }\end{array}$} & $0=$ & Tidak ada (Not available) \\
\hline & & $1=$ & $\begin{array}{l}\text { Ada tetapi tidak berjalan (Available but not } \\
\text { running) }\end{array}$ \\
\hline & & $2=$ & Ada dan berjalan (Available and running well) \\
\hline \multicolumn{4}{|c|}{ Dimensi Teknologi dan Infrastruktur (Techology and Infrastructure Dimensions) } \\
\hline \multirow[t]{3}{*}{1} & \multirow{3}{*}{$\begin{array}{l}\text { Keberadaan industri pengolahan } \\
\text { hasil perikanan / Existence of fish } \\
\text { processing }\end{array}$} & $0=$ & Tidak tersedia (Available) \\
\hline & & $1=$ & $\begin{array}{l}\text { Tersedia tetapi tidak optimal (Available but not } \\
\text { optimal) }\end{array}$ \\
\hline & & $2=$ & Tersedia dan optimal (Available and optimal) \\
\hline \multirow[t]{3}{*}{2} & \multirow{3}{*}{$\begin{array}{l}\text { Keberadaan teknologi informasi } \\
\text { perikanan (Availability } \\
\text { of information on fishery } \\
\text { technology) }\end{array}$} & $0=$ & Tidak tersedia (Available) \\
\hline & & $1=$ & $\begin{array}{l}\text { Tersedia tetapi tidak optimal (Available but not } \\
\text { optimal) }\end{array}$ \\
\hline & & $2=$ & Tersedia dan optimal (Available and optimal) \\
\hline \multirow[t]{3}{*}{3} & \multirow{3}{*}{$\begin{array}{l}\text { Keberadaan industri pengolahan } \\
\text { limbah perikanan /Availability of } \\
\text { fishery waste treantment facility }\end{array}$} & $0=$ & Sangat minim (Very minimal) \\
\hline & & $1=$ & Cukup (Enough) \\
\hline & & $2=$ & Lengkap (Complete) \\
\hline \multirow[t]{3}{*}{4} & \multirow{3}{*}{$\begin{array}{l}\text { Penggunaan teknologi dalam } \\
\text { pengembangan budidaya } \\
\text { perikanan (Use of technology in } \\
\text { aquaculture) }\end{array}$} & $0=$ & Rendah (Low) \\
\hline & & $1=$ & Sedang (Medium) \\
\hline & & $2=$ & Tinggi (High) \\
\hline \multirow[t]{3}{*}{5} & \multirow{3}{*}{$\begin{array}{l}\text { Keberadaan teknologi pakan } \\
\text { (Availability of feed technology) }\end{array}$} & $0=$ & Teknologi tradisional (Traditional technology) \\
\hline & & $1=$ & Teknologi sederhana (Simple technology) \\
\hline & & $2=$ & Teknologi modern (Modern technology) \\
\hline \multirow[t]{3}{*}{6} & \multirow{3}{*}{$\begin{array}{l}\text { Pelaksanaan standarisasi mutu } \\
\text { produk (Implementation of } \\
\text { product quality standardization) }\end{array}$} & $0=$ & $\begin{array}{l}\text { Standarisasi mutu belum diterapkan } \\
\text { (Standardization of quality has not been applied) }\end{array}$ \\
\hline & & $1=$ & $\begin{array}{l}\text { Standarisasi mutu sudah diterapkan pada produk } \\
\text { tertentu (Standardization of quality is applied to } \\
\text { certain products) }\end{array}$ \\
\hline & & $2=$ & $\begin{array}{l}\text { Standarisasi mutu sudah diterapkan untuk semua } \\
\text { produk (Standardization of quality is applied to all } \\
\text { products) }\end{array}$ \\
\hline
\end{tabular}




\section{Lanjutan Tabel 1/Continues Table 1}

\begin{tabular}{|c|c|c|c|}
\hline $\begin{array}{l}\text { No/ } \\
\text { No }\end{array}$ & $\begin{array}{c}\text { Atribut / } \\
\text { Attributes }\end{array}$ & & $\begin{array}{l}\text { Skor/ } \\
\text { Scores }\end{array}$ \\
\hline 7 & $\begin{array}{l}\text { Dukungan sarana dan prasarana } \\
\text { jalan yang memadai (Road } \\
\text { quality and availability) }\end{array}$ & $\begin{array}{l}0= \\
1= \\
2= \\
3=\end{array}$ & $\begin{array}{l}\text { Sangat jelek (Very bad) } \\
\text { Jelek (Bad) } \\
\text { Agak baik (Fair) } \\
\text { Baik (Good) }\end{array}$ \\
\hline 8 & $\begin{array}{l}\text { Dukungan sarana dan prasarana } \\
\text { kesehatan (Health infrastructure } \\
\text { and facility) }\end{array}$ & $\begin{array}{l}0= \\
1= \\
2= \\
3=\end{array}$ & $\begin{array}{l}\text { Sangat jelek (Very bad) } \\
\text { Jelek (Bad) } \\
\text { Agak baik (Fair) } \\
\text { Baik (Good) }\end{array}$ \\
\hline 9 & $\begin{array}{l}\text { Dukungan sarana dan prasarana } \\
\text { pendidikan (Educational } \\
\text { infrastructure and facility) }\end{array}$ & $\begin{array}{l}0= \\
1= \\
2= \\
3=\end{array}$ & $\begin{array}{l}\text { Sangat jelek (Very bad) } \\
\text { Jelek (Bad) } \\
\text { Agak baik (Fair) } \\
\text { Baik (Good) }\end{array}$ \\
\hline 10 & $\begin{array}{l}\text { Dukungan sarana dan prasarana } \\
\text { transportasi (Transportation } \\
\text { infrastructure and facility) }\end{array}$ & $\begin{array}{l}0= \\
1= \\
2= \\
3=\end{array}$ & $\begin{array}{l}\text { Sangat jelek (Very bad) } \\
\text { Jelek (Bad) } \\
\text { Agak baik (Fair) } \\
\text { Baik (Good) }\end{array}$ \\
\hline 11 & $\begin{array}{l}\text { Ketersediaan basis data } \\
\text { (Data base availability) }\end{array}$ & $\begin{array}{l}0= \\
1=\end{array}$ & $\begin{array}{l}\text { Tidak tersedia (Available) } \\
\text { Tersedia tetapi tidak optimal (Available but not } \\
\text { optimal) }\end{array}$ \\
\hline \multirow[t]{3}{*}{12} & $\begin{array}{l}\text { Penerapan sertifikasi produk } \\
\text { perikanan (Implementation } \\
\text { of fishery products quality }\end{array}$ & $\begin{array}{l}2= \\
0=\end{array}$ & $\begin{array}{l}\text { Tersedia dan optimal (Available and optimal) } \\
\text { Sertifikasi produk perikanan belum diterapkan } \\
\text { (Sertification of fishery products has not } \\
\text { beenapplied) }\end{array}$ \\
\hline & certification) & $1=$ & $\begin{array}{l}\text { Sertifikasi produk perikanan sudah diterapkan } \\
\text { pada produk tertentu (Sertification of fishery } \\
\text { productsisappliedtocertain products) }\end{array}$ \\
\hline & & $2=$ & $\begin{array}{l}\text { Sertifikasi produk perikanan sudah diterapkan } \\
\text { untuk semua produk (Sertification of fishery } \\
\text { productsisappliedtoallproducts) }\end{array}$ \\
\hline 13 & $\begin{array}{l}\text { Tingkat pemahaman teknologi } \\
\text { budidaya perikanan (Knowledge } \\
\text { on aquacurture technology) }\end{array}$ & $\begin{array}{l}0= \\
1= \\
2=\end{array}$ & $\begin{array}{l}\text { Rendah (Low) } \\
\text { Sedang (Medium) } \\
\text { Tinggi (High) }\end{array}$ \\
\hline 14 & $\begin{array}{l}\text { Persentase desa yang tidak } \\
\text { memiliki akses penghubung } \\
\text { (Percentage of isolated village) }\end{array}$ & $\begin{array}{l}0= \\
1= \\
2= \\
3=\end{array}$ & $\begin{array}{l}\text { Sangat tinggi (Very high) } \\
\text { Tinggi (High) } \\
\text { Sedang (Medium) } \\
\text { Rendah (Low) }\end{array}$ \\
\hline 15 & $\begin{array}{l}\text { Jumlah desa dengan perikanan } \\
\text { berbasis teknologi (Village with } \\
\text { technologically-oriented fishery) }\end{array}$ & $\begin{array}{l}0= \\
1= \\
2= \\
3=\end{array}$ & $\begin{array}{l}\text { Sangat tinggi (Very high) } \\
\text { Tinggi (High) } \\
\text { Sedang (Medium) } \\
\text { Rendah (Low) }\end{array}$ \\
\hline 16 & $\begin{array}{l}\text { Ketersediaan teknologi untuk } \\
\text { mengatasi permasalahan } \\
\text { dengan pemukiman (Availability } \\
\text { of technology to solve } \\
\text { residential-origin problem) }\end{array}$ & $\begin{array}{l}0= \\
1= \\
2=\end{array}$ & $\begin{array}{l}\text { Jauh (Far) } \\
\text { Sedang (Medium) } \\
\text { Dekat (Near) }\end{array}$ \\
\hline
\end{tabular}


Secara umum, pelaksanaan kegiatan dan analisis data dalam penelitian ini dilakukan mengikuti tahapan seperti diilustrasikan pada Gambar 1.

Secara rinci, tahapan kegiatan dan analisis keberlanjutan dalam penelitian ini mencakup hal-hal sebagai berikut:

1. Penetapan atribut dalam penelitian ini, berdasarkan prosedur dan kriteria pemilihan atribut seperti dijelaskan dalam Kavanagh (2001), ditetapkan 68 atribut yang mencakup 6 dimensi yaitu ekologi (10 atribut), ekonomi (16 atribut), politik (5 atribut), sosial budaya (11 atribut), hukum dan kelembagaan (11 atribut) dan teknologi dan infrastruktur (16 atribut) (Tabel 1).

2. Pelaksanaan mail survey untuk mendapatkan skor bagi semua atrinut terpilih: dilakukan dengan pengiriman kuesioner dengan bentuk pertanyaanpertanyaan tertutup, yang jawabannya

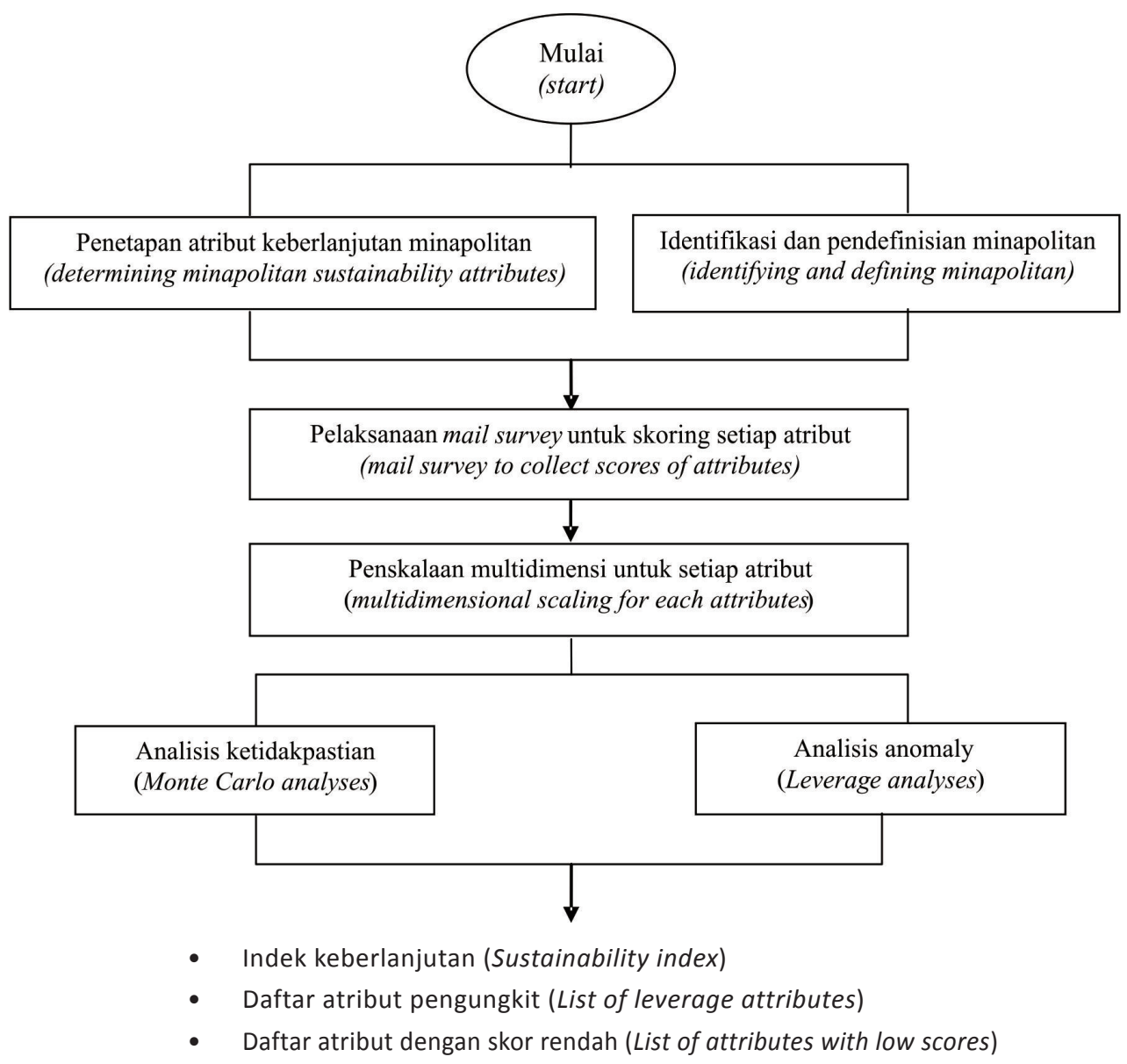

Gambar 1. Bagan Tahapan Kegiatan Untuk Penentuan Indeks Keberlanjutan Program Minapolitan di Lokasi-Lokasi Sesuai Kepmen Kp 32/2010 (Diadaptasi dari Kavanagh, 2001)

Figure 1. Diagramatic Phases for Determining the Minapolitan Sustainability Index in Locations Stated in the Ministerial Decree No. 32/2010 (Adapted From Kavanagh, 2001) 
dikaitkan dengan pembacaan skor dari setiap atribut.

3. Analisis ordinasi RAP-Minapolitan dengan metode MDS dengan menggunakan software SPSS untuk menentukan ordinasi dan nilai stress.

4. Menilai indeks dan status keberlanjutan program Minapolitan yang dikaji secara multidimensi maupun pada setiap dimensi.

5. Analisis sensitivitas (leverage analyses) untuk menentukan peubah yang sensitif mempengaruhi keberlanjutan.

6. Analisis Monte Carlo untuk memperhitungkan aspek ketidakpastian.

Model yang baik ditunjukkan dengan nilai stress yang lebih kecil dari 0,25 atau $\mathrm{S}<0,25$. Skala indeks keberlanjutan sistem yang dikaji mempunyai selang $0-100 \%$. Dalam penelitian ini ada 4 (empat) kategori status keberlanjutan seperti yang terlihat pada Tabel 2.

\section{HASIL DAN PEMBAHASAN}

\section{Hasil Pengujian Kehandalan Hasil Analisis}

Dalam penelitian ini digunakan analisis Monte Carlo untuk menguji tingkat kepercayaan indeks keberlanjutan di masingmasing dimensi dari beberapa pengaruh, diantaranya adalah pengaruh kesalahan pembuatan skor pada setiap atribut pada masing-masing dimensi, kesalahan prosedur atau pemahaman terhadap atribut serta variasi pemberian skor, kesalahan memasukkan data, stabilitas proses analisis MDS dan nilai stress yang terlalu tinggi. Hasil analisis Monte Carlo dapat dilihat pada Tabel 3.

Perbedaan atau selisih antara indeks keberlanjutan MDS dan Monte Carlo relatif kecil menunjukkanbahwa RAP-Mlinapolitan yang menggunakan enam (6) dimensi dengan 68 atribut tersebut: (1) kesalahannya relatif kecil dalam pemberian skor pada setiap atribut, (2) relatif rendah kesalahan variasi pemberian skoring karena perbedaan opini, (3) stabilitas MDS tinggi, (4) kesalahan dalam memasukkan data atau data hilang dapat dihindari, (5) nilai S-Stress yang tinggi dapat dihindari, (6) sistem yang dikaji mempunyai tingkat kepercayaan tinggii, dan (7) metode RAP-MINAPOLITAN cukup baik sebagai salah satu alat evaluasi pelaksanaan program minapolitan di lokasi-lokasi yang sudah ditetapkan sebagai kawasan Minapolitan.

\section{Peta Indeks Keberlanjutan Minapolitan}

Analisis MDS menghasilkan indeks keberlanjutan program Minapolitan di lokasi-lokasi yang sudah ditetapkan sebagai kawasan Minapolitan. Indeks keberlanjutan yang dimaksud menunjukkan besar kecilnya kemungkinan bahwa program Minapolitan akan berlanjut, dilihat dari berbagai dimensi.

Tabel 2. Distribusi Nilai Indeks dan Kategori Untuk Pengukuran Indeks Keberlanjutan Minapolitan di Lokasi-Lokasi Sesuai KEPMEN KP 32/2010

Table 2. Index Value Distribution and Categoryused In Measuring Minapolitan Sustainability Indexin Locations Stated in the Ministerial Decree No. 32/2010

\begin{tabular}{cl}
$\begin{array}{c}\text { Nilai Indeks/ } \\
\text { Index value }\end{array}$ & \multicolumn{1}{c}{ Kategori/Categorize } \\
\hline $0,00-50,00$ & Buruk : tidak berkelanjutan (Bad : Unsustainable) \\
$50,01-6000$ & Kurang : kurang berkelanjutan(Insufficient: Less sustainable) \\
$60,01-70,00$ & Cukup : cukup berkelanjutan(Fair: fairlysustainable) \\
$70,01-100,00$ & Baik : sangat berkelanjutan(Good: very sustainable) \\
\hline
\end{tabular}


Tabel 3. Hasil Analisis Monte Carlodalam Pengkajian Keberlanjutan di Lokasi-Lokasi Sesuai Kepmen KP 32/2010

Table 3. Result of Monte Carlo Analyses of Sustainability Assessment for Locations Stated in the Ministerial Decree No. 32/2010

\begin{tabular}{|c|c|c|c|c|c|}
\hline $\begin{array}{c}\text { Dimensi } \\
\text { (Dimension) }\end{array}$ & $\begin{array}{l}\text { MDS } \\
\text { (MDS) }\end{array}$ & $\begin{array}{l}\text { Monte Carlo } \\
\text { (Monte Carlo) }\end{array}$ & $\begin{array}{l}\text { Perbedaan } \\
\text { (Difference) }\end{array}$ & $\begin{array}{l}\text { Stress } \\
\text { (Stress) }\end{array}$ & $\begin{array}{c}\mathrm{R}^{2} \\
\text { (Squarred } \\
\text { Correlation) }\end{array}$ \\
\hline Ekologi (Ecology) & 51,64 & 51,93 & 0,29 & 0,249 & 0,807 \\
\hline Ekonomi (Economy) & 56,90 & 56,62 & 0,28 & 0,205 & 0,881 \\
\hline Politik (Political) & 86,63 & 82,79 & 3,84 & 0,189 & 0.931 \\
\hline $\begin{array}{l}\text { Sosial budaya (Socio } \\
\text { cultural) }\end{array}$ & 69,24 & 65,97 & 3,27 & 0,223 & 0,877 \\
\hline $\begin{array}{l}\text { Hukum dan } \\
\text { kelembagaan } \\
\text { (Legal and institutional) }\end{array}$ & 82,95 & 77,95 & 5,00 & 0,198 & 0,893 \\
\hline $\begin{array}{l}\text { Teknologi dan } \\
\text { infrastruktur } \\
\text { (Technology and } \\
\text { infrastructure) }\end{array}$ & 51,42 & 51,79 & 0,37 & 0,184 & 0,909 \\
\hline
\end{tabular}

Sumber: Data primer diolah (2010)/Source: Primary data, processed (2010)

Gambar 2 menampilkan hasil pengukuran indeks keberlanjutan di 99 lokasi Minapolitan yang tersebar di seluruh Indonesia. Terlihat pada gambar tersebut bahwa dengan kondisi kini yang teridentifikasi di lapangan, sebagian lokasi mempunyai prospek keberlanjutan yang tinggi, sebagian lain sedang, sebagian lainnya rendah.

Indeks keberlanjutan ditentukan oleh kondisi kini di lapangan, yang berarti bahwa indeks tersebut dapat berubah menjadi baik atau menjadi lebih buruk, tergantung pada perubahan atau upaya-upaya yang diarahkan untuk melakukan perubahan pada kondisi dari atribut-atribut tersebut. Sebagian dari atribut tersebut dapat dikategorikan sebagai atribut sensitif, sehingga dapat dipandang sebagai faktor pengungkit. Untuk itu, bagian di bawah ini, selain menampilkan hasil analisis ordinansi, juga mempresentasikan hasil analisis anomali (leverage analyses), yang mengindikasikan sensitivitas dari setiap atribut pada masing-masing dimensi.

\section{Hasil Analisis Ordinansi dan Analisis Leverage Dimensi Ekologi}

Dimensi ekologi menyertakan 10 atribut untuk analisis keberlanjutan sebagaimana yang disajikan pada Tabel 1 . Hasil analisis menunjukkan bahwa indeks keberlanjutan untuk dimensi ekologi secara nasional adalah 51,64\% dalam skala keberlanjutan 0 - 100, artinya kurang berkelanjutan, nilai stress 0,249 dan nilai R2 $=0,807$. Menurut Kavanagh (2001), nilai stress yang diperbolehkan adalah kurang dari 0,25. Dari hasil analisis leverage keberlanjutan dimensi ekologi seperti yang disajikan pada Gambar 3, dari 10 atribut yang dianalisis, diketahui bahwa tiga (3) atribut paling mempengaruhi keberlanjutan program Minapolitan pada dimensi ini adalah: (1) jarak lokasi usaha perikanan dengan pemukiman penduduk,(2) kejadian kekeringan dan (3) produktivitas usaha perikanan. Ketiga atribut juga teridentifikasi di lapangan sebagai atribut yang kondisinya sangat buruk. Interpretasi praktikal dari hasil ini 


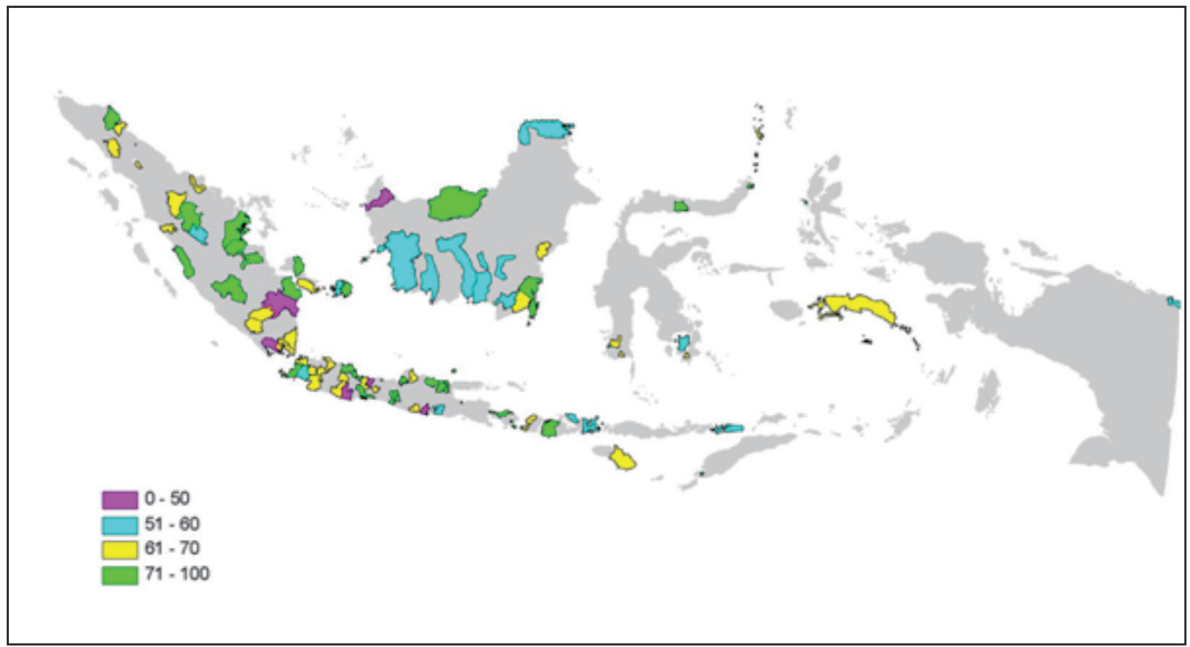

Gambar 2. Peta Sebaran Nilai Keberlanjutan Program Minapolitan untuk lokasi-lokasi sesuai Kepmen KP 32/2010

Figure 2. Map of the Sustainability Value Distributionof Minapolitan Program in locations Stated in the Ministerial Decree No. 32/2010
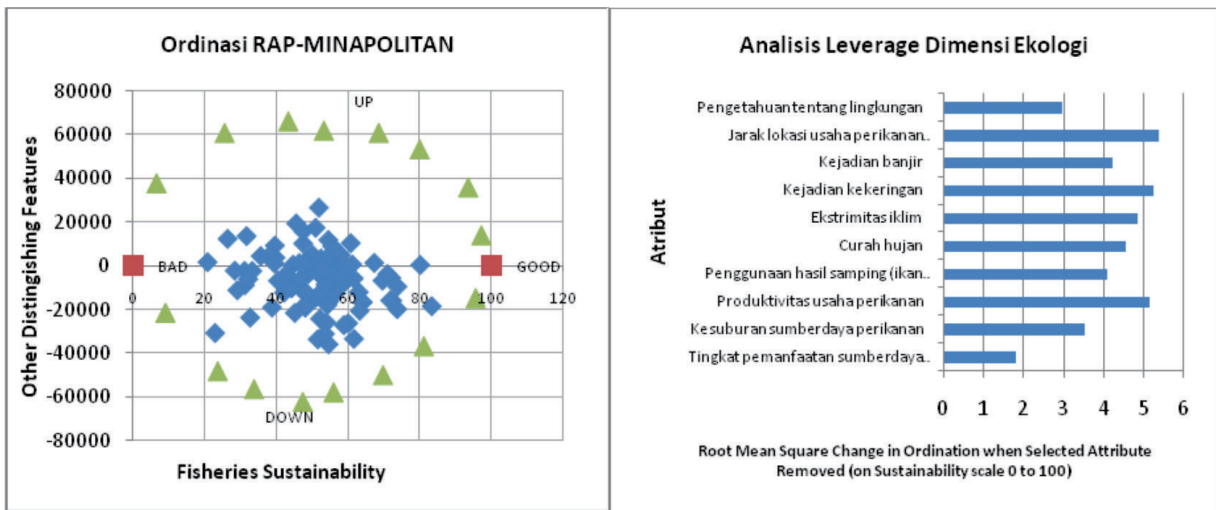

Gambar 3. Analisis Keberlanjutan Dimensi Ekologi dan Faktor Pengungkit yang Mempengaruhi Keberlanjutan Program Minapolitanuntuk lokasi-lokasi sesuai Kepmen KP 32/2010

Figure 3. Ecological Dimension of Sustainability Analysis and Leverage Factors Affecting the Sustainability of Minapolitan Program in Locations stated in the Ministerial Decree No. 32/2010

adalah bahwa sedikit peningkatan atau penurunan kondisi dari ketiga tersebut akan berakibat signifikan pada dimensi keberlanjutan; dan hasil pengukuran di lapangan terhadap kondisi dari atribut-atribut tersebut mengarah pada sebuah implikasi bahwa prioritas perbaikan harus ditujukan pada ketiga atribut tersebut, yaitu mengupayakan pengembangan lokasi-lokasi usaha agar tidak terlalu dekat dengan lokasi permukiman, mengantisipasi kejadian kekeringan, dan mengkonsentrasikan pada aspek produktivitas usaha perikanan. 


\section{Hasil Analisis Ordinansi dan Analisis Leverage Dimensi Ekonomi}

Gambar 4 menunjukkan nilai indeks keberlanjutan untuk dimensi ekonomi sebesar 56,90\%, dengan kategori kurang berkelanjutan, dengan nilai stress 0,205 dan nilai R2 $=0,881$. Berdasarkan hasil analisis Leverage terhadap dimensi tersebut, seperti yang disajikan pada Gambar 2, dari 16 atribut yang dianalisis diidentifikasi tiga (3) atribut tersensitif yang mempengaruhi keberlanjutan program minapolitan, yaitu: (1) ketersediaan SDM perikanan, (2) kelayakan usaha perikanan dan (3) keuntungan dalam usaha perikanan. Dari ketiganya, atribut pertama teridentifikasi di lapangan sebagai atribut yang kondisinya paling buruk. Interpretasi praktikal dari hasil ini adalah bahwa sedikit peningkatan atau penurunan kondisi dari ketiga tersebut akan berakibat signifikan pada dimensi keberlanjutan. Namun demikian, hasil pengukuran kondisi atribut-atribut tersebut di lapangan mengarah pada sebuah implikasi bahwa prioritas perbaikan harus ditujukan pada atribut pertama, yaitu mengupayakan ketersediaan SDM perikanan berkualitas.

\section{Hasil Analisis Ordinansi dan Analisis Leverage Dimensi Politik}

Hasil perhitungan menunjukkan bahwa indeks keberlanjutan untuk dimensi politik adalah $86,63 \%$, sehingga dapat dimasukkan ke dalam kategori sangat berkelanjutan, dengan nilai stress 0,189 dan nilai $\mathrm{R} 2=0,931$. Dari hasil analisis leverage keberlanjutan dimensi politik seperti yang disajikan pada Gambar 5, dari lima atribut yang dianalisis tiga atribut tersensitif yang mempengaruhi keberlanjutan program minapolitan adalah: (1) sinkronisasi kebijakan pusat dan daerah, (2) kecendrungan politik lokal (kabupaten) dan (3) dominasi kelompok politik tertentu. Ketiga tersebut juga teridentifikasi di lapangan sebagai atribut yang kondisinya sangat buruk. Interpretasi praktikal dari hasil ini adalah bahwa sedikit peningkatan atau penurunan kondisi dari ketiga tersebut

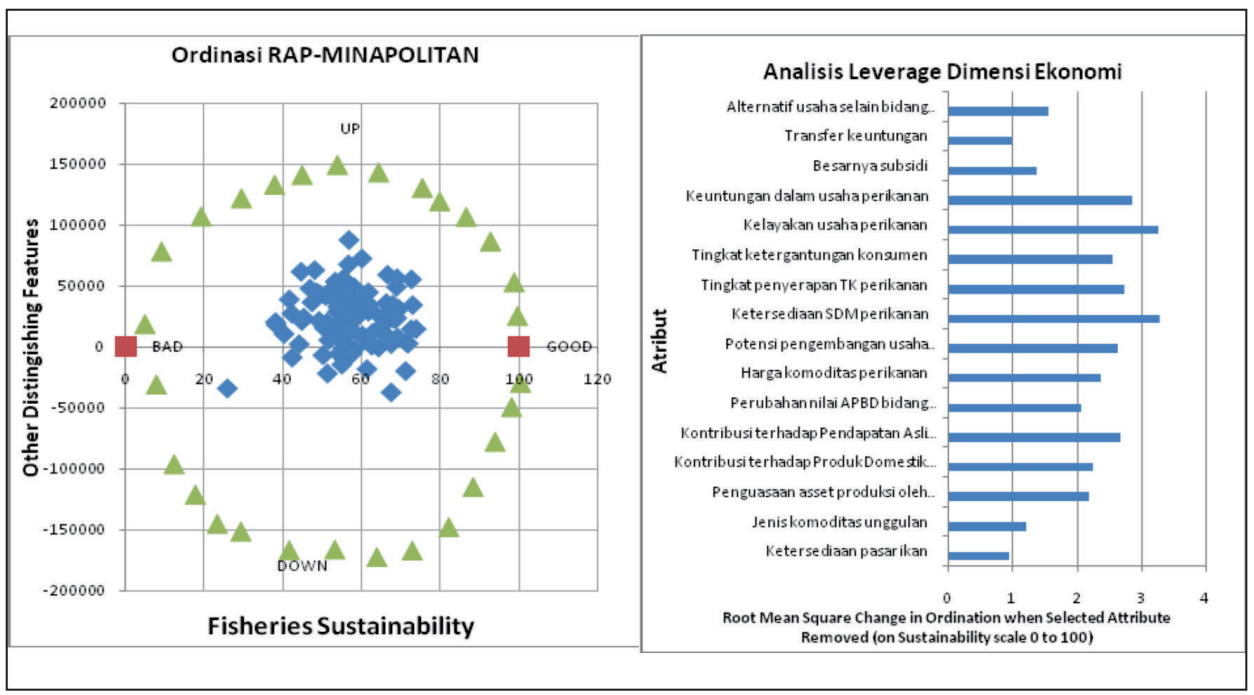

Gambar 4. Analisis Keberlanjutan Dimensi Ekonomi dan Faktor Pengungkit yang Mempengaruhi Keberlanjutan Program Minapolitanuntuk lokasi-lokasi sesuai Kepmen KP 32/2010

Figure 4. Economic dimension of sustainability analysis and leverage factors affecting the sustainability of minapolitan programin locations stated in the Ministerial Decree No. 32/2010 


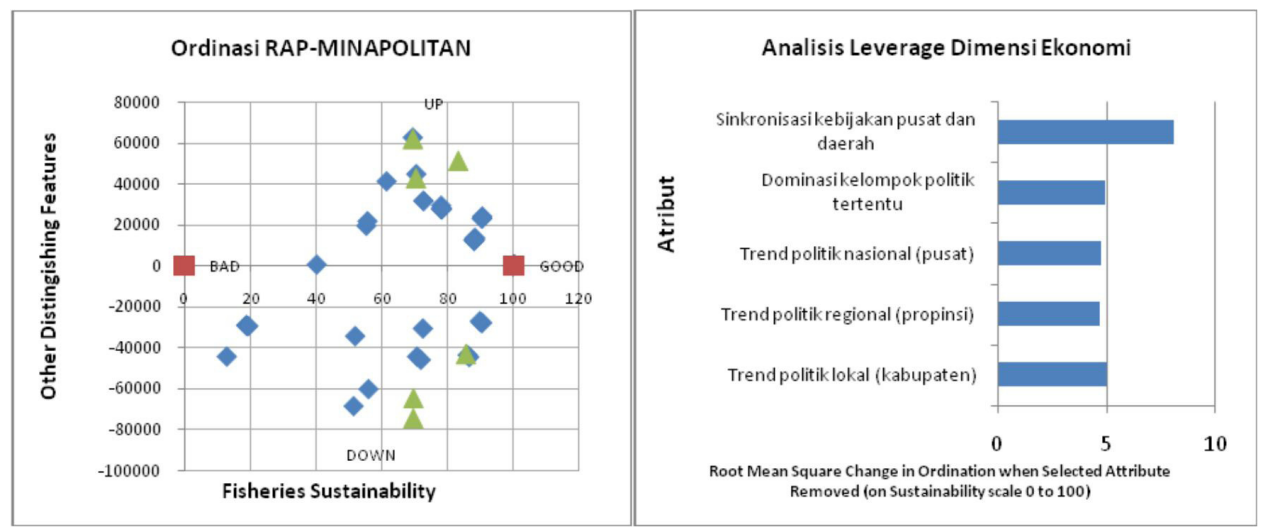

Gambar 5. Analisis Keberlanjutan Dimensi Politik dan Faktor Pengungkit yang Mempengaruhi Keberlanjutan Program Minapolitan untuk lokasi-lokasi sesuai Kepmen KP $32 / 2010$

Figure 5. Political Dimension of Sustainability Analysis and Leverage Factors Affecting the Sustainability of Minapolitan Programing Locations Stated in the Ministerial Decree No. 32/2010

akan berakibat signifikan pada dimensi keberlanjutan. Hal ini membawa implikasi bahwa prioritas perbaikan harus ditujukan pada ketiga atribut tersebut, termasuk peningkatkan sinkronisasi kebijakan pusat-daerah, mendorong politiklokal yang lebih mendukung program minapolitan, dan mengurangi dominasi kelompok politik tertentu.

\section{Hasil Analisis Ordinansi dan Analisis Leverage Sosial Budaya}

Hasil analisis keberlanjutan dimensi sosial budaya menghasilkan nilai keberlanjutan sebesar 69,24\%, sehingga termasuk kategori cukup berkelanjutan, dengan nilai stress 0,223 dan nilai $R 2=0,877$. Berdasarkan hasil analisis leverage keberlanjutan dimensi sosial budaya seperti yang disajikan pada Gambar 6, dari 11 atribut yang dianalisis diketahui tiga (3) atribut tersensitif terhadap keberlanjutan program minapolitan adalah: (1) akses masyarakatterhadapperikanan, (2) frekuensi konflik dan(3) peran masyarakat adat dalam kegiatan perikanan. Dari ketiganya, atribut pertama dan ketiga teridentifikasi di lapangan sebagai atribut yang kondisinya paling buruk. Interpretasi praktikal dari hasil ini adalah bahwa sedikit peningkatan atau penurunan kondisi dari ketiga tersebut akan berakibat signifikan pada dimensi keberlanjutan. Hal ini membawa implikasi bahwa prioritas perbaikan harus ditujukan pada atribut pertama dan ketiga, yaitu dengan meningkatkan akses masyarakat dan peran adat.

\section{Hasil Analisis Ordinansi dan Analisis Leverage Dimensi Hukum dan Kelembagaan}

Seperti terlihat pada Gambar 7, nilai keberlanjutan untuk dimensi hukum dan kelembagaan sebesar 82,95\%, sehingga termasuk kategori sangat berkelanjutan karena berada pada selang 75,01 100,00 dengan nilai stress 0,198 dan nilai R2 $=0,893$. Berdasarkan hasil analisis Leverage keberlanjutan dimensi hukum dan kelembagaan bahwa dari 10 atribut yang dianalisis diketahui tiga atribut tersensitif yang berpengaruh terhadap keberlanjutan program minapolitan adalah: (1) keberadaan kelompok nelayan dan pembudidaya, (2) keberadaan lembaga sosial dan (3) Keberadaan lembaga keuangan mikro. Dari ketiganya, tidak ada satupun atribut yang teridentifikasi di lapangan sebagai atribut dengan kondisi 


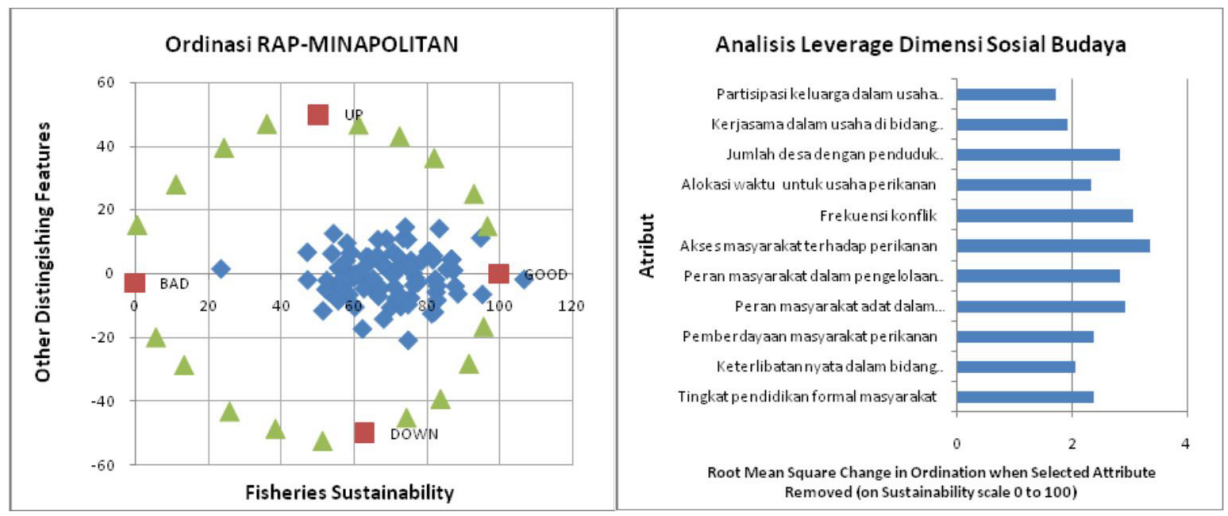

Gambar 6. Analisis Keberlanjutan Dimensi Sosial Budaya dan Faktor Pengungkit yang Mempengaruhi Keberlanjutan Program Minapolitanuntuk lokasi-lokasi sesuai Kepmen KP 32/2010

Figure 6. Socio Cultural Dimension of Sustainability Analysis and Leverage Factors Affecting the Sustainability of Minapolitan Programing Locations Stated in the Ministerial Decree No. 32/2010

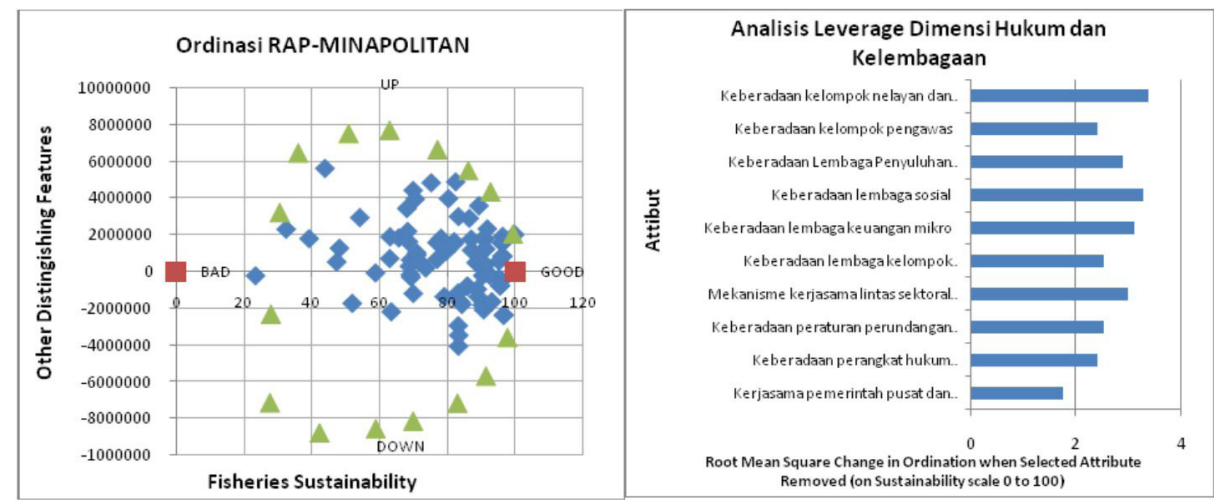

Gambar 7. Analisis Keberlanjutan Dimensi Hukum dan Kelembagaan dan Faktor Pengungkit yang Mempengaruhi Keberlanjutan Program Minapolitanuntuk lokasi-lokasi sesuai Kepmen KP 32/2010

Figure 7. Legal and Institutional Dimension of Sustainability Analysis and Leverage Factors Affecting the Sustainability of Minapolitan Programing Locations Stated in the Ministerial Decree No. 32/2010

sangat buruk. Interpretasi praktikal dari hasil ini adalah bahwa sedikit peningkatan atau penurunan kondisi dari ketiga tersebut akan berakibat signifikan pada dimensi keberlanjutan. Namun, pengamatan kondisi di lapang menunjukkan bahwa secara umum atributatribut tersebut bukan atribut prioritas.
8. Hasil Analisis Ordinansi dan Analisis Leverage Dimensi Teknologi dan Infrastruktur

Nilai keberlanjutan untuk dimensi teknologi dan infrastruktur adalah sebesar 51,42\%, dengan status kurang berkelanjutan, nilai stress 0,184 dan nilai $\mathrm{R} 2=0,909$. Berdasarkan hasil analisis Leverage 
keberlanjutan dimensi teknologi dan infrastruktur (Gambar 8), diperoleh bahwa dari 16 atribut yang dianalisis, tiga (3) atribut yang berpengaruh tersensitif terhadap keberlanjutan program minapolitan adalah: (1) dukungan sarana dan prasarana pendidikan, (2) dukungan sarana dan prasarana kesehatan dan (3) ketersediaan industri pengolahan limbah perikanan. Dari ketiganya, atribut ketiga teridentifikasi di lapangan sebagai atribut yang kondisinya paling buruk. Interpretasi praktikal dari hasil ini adalah bahwa sedikit peningkatan atau penurunan kondisi dari ketiga tersebut akan berakibat signifikan pada dimensi keberlanjutan. Hal ini membawa implikasi bahwa prioritas perbaikan harus ditujukan pada atribut ketiga, yaitu mengupayakan ketersediaan industri pengolahan limbah perikanan di lokasi-lokasi minapolitan.

\section{Interpretasi Hasil dan Perumusan Arah Kebijakan}

Berdasarkan hasil analisis ordinasi menggunakan RAP-Minapolitan seperti yang telah disajikan pada Gambar 3 sampai 8, didapatkan bahwa dimensi teknologi dan infrastruktur memiliki nilai indeks keberlanjutan yang paling rendah. Gambar 8 dimaksudkan untuk menampilkan pembandingan yang lebih jelas. Terlihat pada gambar tiga dimensi tersebut bahwa dimensi teknologi dan infrastruktur mempunyai nilai yang rendah, sehingga dapat dipandang sebagai atribut-atribut (kondisi eksisting) dari dimensi yang sensitif tersebut yang perlu mendapatkan perhatian utama atau memerlukan intervensi kebijakan serta perbaikan yang signifikan.

Terkait dengan perlunya prioritas perhatian dan intervensi kebijakan, berikut adalah bahasan yang didasarkan atas interpretasi hasil-hasil analisis Leverage yang dikaitkan dengan hasil skoring untuk masing-masing atribut sensitif. Tabel 3 menunjukkan skor dari atribut-atribut sensitif tersebut.

Mengacu pada Tabel 3, diantara tiga atribut tersensitif untuk masing-masing dimensi, terdapat atribut-atribut yang pada umumnya (rata-rata secara nasiona) mendapatkan skor rendah, yaitu kurang dari 1,25. Untuk atribut ini, intervensi kebijakan dapat diharapkan akan meningkatkan indeks keberlanjutan secara signifikan untuk dimensi-dimensi

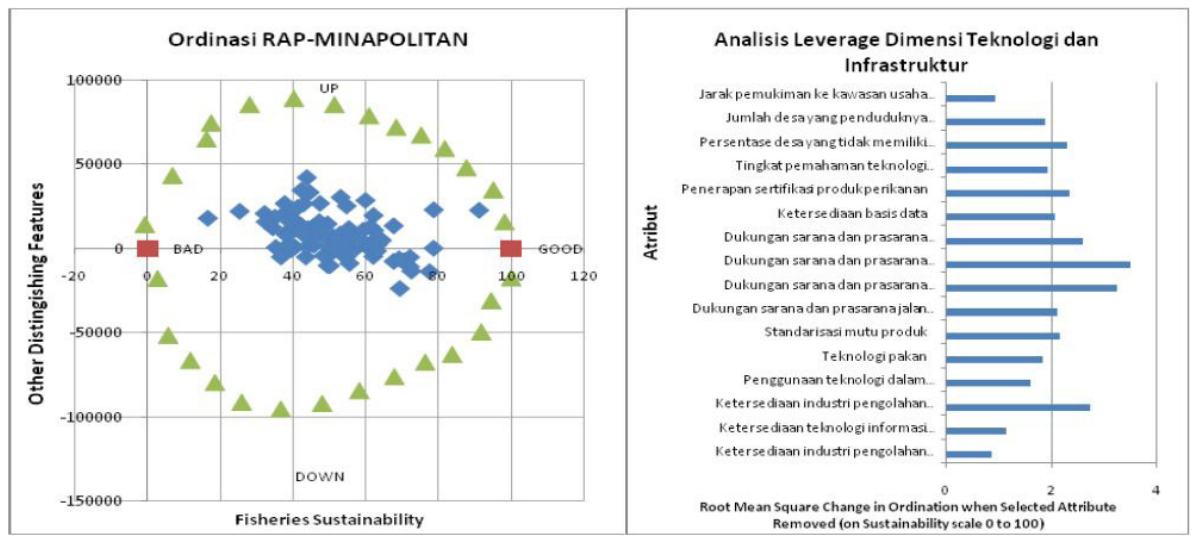

Gambar 8. Analisis Keberlanjutan Dimensi Teknologi dan Infrastruktur dan Faktor Pengungkit yang Mempengaruhi Keberlanjutan Program Minapolitanuntuk lokasi-lokasi sesuai Kepmen KP 32/2010

Figure 8. Technology and Infrastructure Dimension of Sustainability Analysis and Leverage Factors Affecting the Sustainability of Minapolitan Programing Locations Stated in the Ministerial Decree No. 32/2010 


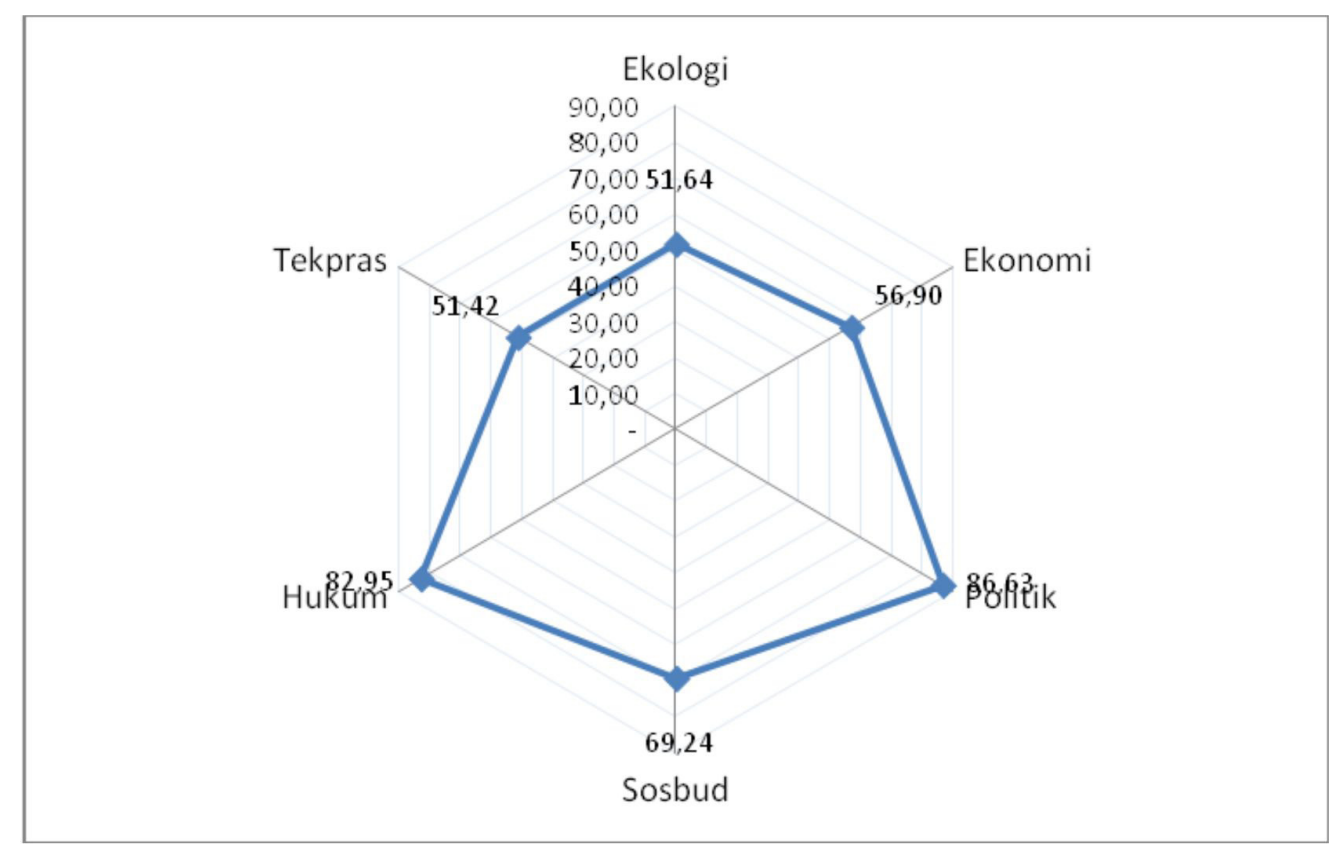

Gambar 9. Diagram Layang (Indeks) Keberlanjutan Program Minapolitan untuk lokasi-lokasi sesuai Kepmen KP 32/2010

Figure 9. Sustainability Index of Six Dimension of the Minapolitan Program on Each Locations Stated in the Ministerial Decree No. 32/2010

Tabel 3. Skor Faktor Pengungkit menurut Dimensi dalam Program Minapolitan untuk lokasilokasi sesuai Kepmen KP 32/2010

Table 3. Scores Leverage Factor by Dimensions of Minapolitan Program in Locations Stated in the Ministerial Decree No. 32/2010

\begin{tabular}{|c|c|c|c|}
\hline $\begin{array}{l}\text { No/ } \\
\text { No }\end{array}$ & $\begin{array}{l}\text { Dimensi/ } \\
\text { Dimension }\end{array}$ & $\begin{array}{l}\text { Faktor Pengungkit/ } \\
\text { Leverage Factors }\end{array}$ & $\begin{array}{l}\text { Skor/ } \\
\text { Scores }\end{array}$ \\
\hline \multirow[t]{3}{*}{1} & Ekologi (Ecology) & $\begin{array}{l}\text { (1) Jarak lokasi usaha perikanan dengan pemuki- } \\
\text { man penduduk/ Distance of business centers to } \\
\text { residence }\end{array}$ & 1,1 \\
\hline & & (2) Kejadian kekeringan/ Drought event & 1,1 \\
\hline & & $\begin{array}{l}\text { (3) Produktivitas usaha perikanan/ Fisheries business } \\
\text { productivity }\end{array}$ & 1,1 \\
\hline \multirow[t]{3}{*}{2} & $\begin{array}{l}\text { Ekonomi } \\
\text { (Economy) }\end{array}$ & $\begin{array}{l}\text { (1) Ketersediaan SDM perikanan/ Availability of fish- } \\
\text { ery human resources }\end{array}$ & 0,9 \\
\hline & & $\begin{array}{l}\text { (2) Kelayakan usaha perikanan/ Fisheries business } \\
\text { feasibility }\end{array}$ & 1,9 \\
\hline & & $\begin{array}{l}\text { (3) Keuntungan dalam usaha perikanan/ Profit in } \\
\text { fisheries business }\end{array}$ & 3,4 \\
\hline
\end{tabular}


Lanjutan Tabel 3/Continues Table 3

\begin{tabular}{|c|c|c|c|}
\hline $\begin{array}{l}\text { No/ } \\
\text { No }\end{array}$ & $\begin{array}{l}\text { Dimensi/ } \\
\text { Dimension }\end{array}$ & $\begin{array}{l}\text { Faktor Pengungkit/ } \\
\text { Leverage Factors }\end{array}$ & $\begin{array}{l}\text { Skor/ } \\
\text { Scores }\end{array}$ \\
\hline \multirow[t]{3}{*}{3} & \multirow[t]{3}{*}{$\begin{array}{l}\text { Politik } \\
\text { (Political) }\end{array}$} & $\begin{array}{l}\text { (1) Sinkronisasi kebijakan pusat dan daerah/ Harmo- } \\
\text { ny between local and national policies }\end{array}$ & \multirow[t]{3}{*}{1,6} \\
\hline & & $\begin{array}{l}\text { (2) Trend politik lokal (kabupaten)/ } \\
\text { Local (Regency) political trend }\end{array}$ & \\
\hline & & $\begin{array}{l}\text { (3) Dominasi kelompok politik tertentu/ } \\
\text { Domination of particular political group }\end{array}$ & \\
\hline \multirow[t]{3}{*}{4} & \multirow[t]{3}{*}{$\begin{array}{l}\text { Sosial budaya } \\
\text { (Socio cultural) }\end{array}$} & $\begin{array}{l}\text { (1) Akses masyarakat terhadap perikanan/ } \\
\text { People access to fisheries }\end{array}$ & 0,9 \\
\hline & & (2) Frekuensi konflik/ Frequency of conflict & 1,3 \\
\hline & & $\begin{array}{l}\text { (3) Peran masyarakat adat dalam kegiatan perikanan/ } \\
\text { Role of customary arrangement in fisheries }\end{array}$ & 1,2 \\
\hline \multirow[t]{3}{*}{5} & \multirow{3}{*}{$\begin{array}{l}\text { Hukum dan } \\
\text { kelembagaan } \\
\text { (Legal and institu- } \\
\text { tional) }\end{array}$} & $\begin{array}{l}\text { (1) Keberadaan kelompok nelayan dan pembudidaya/ } \\
\text { Availability of fishers group }\end{array}$ & 1,9 \\
\hline & & $\begin{array}{l}\text { (2) Keberadaan lembaga sosial/ } \\
\text { Availability ofsocial institution }\end{array}$ & 1,6 \\
\hline & & $\begin{array}{l}\text { (3) Keberadaan lembaga keuangan mikro/ Availability } \\
\text { of micro financing mechanism }\end{array}$ & 1,6 \\
\hline \multirow[t]{3}{*}{6} & \multirow{3}{*}{$\begin{array}{l}\text { Teknologi dan } \\
\text { infrastruktur } \\
\text { (Technology ad } \\
\text { infrastructure) }\end{array}$} & $\begin{array}{l}\text { (1) Dukungan sarana dan prasarana pendidikan/ } \\
\text { Educational infrastructure and facility }\end{array}$ & 2,4 \\
\hline & & $\begin{array}{l}\text { (2) Dukungan sarana dan prasarana kesehatan/ } \\
\text { Health infrastructure and facility }\end{array}$ & 2,3 \\
\hline & & $\begin{array}{l}\text { (3) Ketersediaan industri pengolahan limbah perikan- } \\
\text { an/ Availability of fishery waste treatment facility) }\end{array}$ & 0,1 \\
\hline
\end{tabular}

terkait. Atribut-atribut tersebut adalah:

- Jarak lokasi usaha perikanan dengan pemukiman, kejadian kekeringan, produktivitas usaha (dimensi ekologi)

- Ketersediaan SDM perikanan (dimensi ekonomi)

- Sinkronisasi kebijakan pusat-daerah, trend politik lokal dan dominasi kelompok politik tertentu (dimensi politik)

- Akses masyarakat terhadap perikanan dan peran masyarakat adat (dimensi sosial dan budaya)

- Ketersediaan idustri pengolahan limbah (dimensi sarana dan prasarana).

\section{KESIMPULAN DAN IMPLIKASI KEBIJAKAN}

\section{Kesimpulan}

Program minapolitan secara umum memiliki prospek keberlanjutan yang sangat tinggi apabila dilihat dari dimensi politik, hukum dan kelembagaan. Dari kota $\bigvee$ kabupaten yang disurvey, 31,41\% dapat diketegorikan sangat berkelanjutan, $41,41 \%$ cukup berkelanjutan, 21,21\% kurang berkelanjutan, 6,06\% tidak berkelanjutan. Namun demikian, berdasarkan data dan analisis multi aspek di lapangan, program tersebut menunjukkan peluang keberlanjutan yang rendah pada dimensi ekologi,teknologi, infrastruktur dan ekonomi. 
Sejumlah atribut teridentifikasi sebagai atribut pengungkit, yang bersifat sensitif, yang berpengaruh signifikan pada tinggi rendahnya prospek keberlanjutan dari berbagai dimensi tersebut. Dan di antara atribut sensitif tersebut, terdapat di antaranya yang pada saat ini dalam kondisi yang buruk. Sepuluh atribut yang teridentifikasi sensitif dan berada dalam kondisi lemah / buruk adalah: (1) jarak lokasi usaha perikanan, yang pada umumnya terlalu menyatu dengan pemukiman, (2) banyaknya lokasi yang terpengaruh oleh kejadian kekeringan, (3) rendahnya rata-rata produktivitas usaha, (4) minimnya ketersediaan SDM perikanan, (5) kurangnya sinkronisasi kebijakan pusat - daerah, (6) trend politik local yang pada umumnya kurang mendukung, (7) dominasi kelompok politik tertentu, (8) rendahnya akses masyarakat terhadap perikanan, (9) kurangnya peran masyarakat adat, dan (10) kurangnya ketersediaan industri pengolahan limbah. Implikasi dari hal ini adalah perlunya intervensi kebijakan yang diarahkan pada perbaikan kondisi di lapangan yang terkait dengan atributatribut pengungkit yang saat ini dalam kondisi lemah tersebut.

\section{Implikasi Kebijakan}

1. Perlunya mempersiapkan formulasi intervensi kebijakan, yang diarahkan pada perbaikan kondisi di lapangan yang terkait dengan atribut-atribut pengungkit yang saat ini dalam kondisi lemah. Program minapolitan dilakukan melalui pemberdayaan masyarakat dimana keberhasilannya diukur dari perubahan pola pikir dan perilakunya. Hal ini dapat dimulai dengan melakukan sosialisasi program minapolitan secara menyeluruh kepada masyarakat sebagai salah satu upaya untuk memperbaiki kondisi lemah di lapangan.

2. Perlunya pengkajian lanjut tentang peluang dan tantangan dalam memilih bentuk-bentuk intervensi terkait atribut- atribut tersebut. Peluangnya adalah bahwa program minapolitan merupakan programlintaskementerianyangdifokuskan pada pembangunan wilayah perdesaan. Adapun tantangan pencapaiannya adalah proses yang membutuhkan konsistensi, dedikasi dan komitmen yang kuat pada tujuan pembangunan nasional.

\section{DAFTAR PUSTAKA}

Anonimous. 2009. Kebijakan Pengembangan Kawasan Minapolitan Sebagai Langkah DKP dalam Mendukung Pengembangan Wilayah. Direktorat Jenderal Perikanan Budidaya.

2009. Pengembangan Minapolitan. Makalah disampaikan di Makassar, 6 Desember 2009. Direktorat Jenderal Perikanan Tangkap. Jakarta.

. 2010. Keputusan Menteri Kelautan dan Perikanan No 32/MEN/2010 tentang Penetapan Kawasan Minapolitan. Kementerian Kelautan dan Perikanan. Jakarta.

Beller J. 1990. A Moral Reasoning Intervention Program for Division I Athletes Can Athletes Learn Not to Cheat? Dissertation, College of Graduate Studies, University of Idaho.

Dahuri R. 2004. Pengelolaan Sumber Daya Wilayah Pesisir dan Lautan Secara Terpadu. Edisi Revisi. Pradnya Paramita. Jakarta.

Dalay-Clayton B \& S. Bass. 2002. Sustainable Development Strategies, A Resource Book. Organization for Economic Co-Operation and development. United Nation Development Programme. Earthscan Publication Ltd, London.

Fauzi, A. dan S. Anna. 2005. Pemodelan Sumberdaya Perikanan dan Kelautan untuk Analisis Kebijakan. Gramedia Pustaka Utama. Jakarta. 352 hal.

Gallopin G. 2003. A System Approach to Sustainability and Sustainable Development and Human Settlement Division. Nations Unidas Santiago, Chili. 
Kavanagh P. 2001. Rapid Appraisal of Fisheries (Rapfish) Project. Rapfish Software Description (for Microsoft Excel). University of British Columbia, Fisheries Center. Vancouver.

Kavanagh, P and TT Pitcher. 2004. Implementing Microsoft Excel Software for Rapfish : A Technique for The Projectfor The Rapid Appraisal of Fisheries Status. University of British Columbia, Fisheries Center Research Reports 12 (2) ISSN: 1198 - 672. Canada. 75 pp.

Kay, R. dan J. Alder. 1999. Coastal Planning and Management. Routledge. New York.

Munasinghe M. 1993. Environmental Rconomic and Sustainable Development. The International Bank for Reconstruction and Development. The World Bank. Washington DC

Pitcher TJ, A Bundy, D Preikshot, T Hutton, and D Pauly. 1998. Measuring The Unmeasurable: A Multivariate Interdisciplinary Method for Rapid Appraisal of Health Of Fisheries. Pages 31-54 in Pitcher, T.J. Hart, P.J.B. and Pauly, D. (Eds) ReinventingFisheries Management Chapman and Hall, London. 435pp.
Pitcher T.J., S. Mackinson, M. Vasconcellos, L. Nøttestad and D Preikshot. 1999. Rapid Appraisal of The Status of Fisheries for Small Pelagics Using Multivariate, Multidisciplinary Ordination. Pages 759-782 in T.J. Quinn II, F. Funk, J. Heifetz, J.N.Ianelli, J.E. Powers, J.F. Schweigert, P.J. Sullivan, C.-I. Zhang (eds), Fishery StockAssessment Models. Alaska Sea Grant, Fairbanks.

Preikshot D.B. and D. Pauly. 1999. A multivariate interdisciplinary assessment of smallscale tropical fisheries. Pages 803-814 in T.J. Quinn II, F. Funk, J. Heifetz, J.N. lanelli,J.E. Powers, J.F. Schweigert, P.J. Sullivan, C.-I. Zhang (eds), Fishery Stock AssessmentModels. Alaska Sea Grant, Fairbanks.

WCED. 1987. Our Common Future. Oxford Univ. Press. New York. 